\title{
Chemical Aspects of Bacterial Nanocellulose
}

\author{
Gennadij V. Sakovicha, \\ Ekaterina A. Skiba ${ }^{a}$, Evgeniya K. Gladysheva ${ }^{a}$, \\ Vera V. Budaeva*a and Lyudmila A. Aleshina ${ }^{b}$ \\ ${ }^{a}$ Institute for Problems of Chemical \\ and Energetic Technologies SB RAS \\ 1 Socialisticheskaya Str., Biysk, 659322, Russia \\ ${ }^{b}$ Petrozavodsk State University \\ 33 Lenin, Petrozavodsk, Republic of Karelia, 185910, Russia
}

Received 25.10.2018, received in revised form 01.11.2018, accepted 30.11.2018

\begin{abstract}
A synthetic procedure for bacterial nanocellulose (BNC) from oat hulls is suggested herein. This procedure involves several stages: chemical pretreatment of feedstock followed by successive treatment with dilute sodium hydroxide and nitric acid; enzymatic hydrolysis of pulp; synthesis of $B N C$ by the Medusomyces gisevii Sa-12 microorganism on a nutrient broth obtained from enzymatic hydrolyzate; and BNC washing. The yield of dry BNC was $4.8 \%$ and the degree of polymerization was 2010. The IR spectroscopy confirmed the cellulose chemical purity, the TGA analysis confirmed the typical decomposition of the polymer, and the SEM analysis showed that BNC had an intrinsic nanoscale network structure. X-ray diffraction revealed that the BNC had 99\% triclinic Io allomorph and $88 \%$ crystallinity index.
\end{abstract}

Keywords: bacterial nanocellulose, chemical aspects, I $\alpha$ allomorph, crystallinity index.

Citation: Sakovich G.V., Skiba E.A., Gladysheva E.K., Budaeva V.V., Aleshina L.A. Chemical aspects of bacterial nanocellulose, J. Sib. Fed. Univ. Chem., 2018, 11(4), 531-542. DOI: 10.17516/1998-2836-0097.

(C) Siberian Federal University. All rights reserved

* Corresponding author E-mail address: budaeva@ipcet.ru 


\section{Химические аспекты}

\section{бактериальной наноцеллюлозы}

Г.В. Сакович ${ }^{a}$, Е.А. Скиба ${ }^{a}$, Е.К. Гладышева ${ }^{a}$, В.В. Будаева ${ }^{a}$, Л.А. Алешина ${ }^{6}$ ${ }^{a}$ Институт проблем химико-энергетических технологий СО РАН Россия, 659322, Бийск, ул. Социалистическая, 1 ${ }^{6}$ Петрозаводский государственный университет Россия,185910, Республика Карелия, Петрозаводск, пр. Ленина, 33

Предложен способ синтеза бактериальной наночеллюлозы из плодовых оболочек овса. Способ получения включает в себя несколько стадий: предварительную химическую обработку сырья с последовательным использованием разбавленных растворов гидроксида натрия и азотной кислоты; форментативный гидролиз технической целлюлозы; синтез бактериальной наноцеллюлозы продуцентом Medusomyces gisevii Sa-12 на питательной среде ферментативного гидролизата; промывку бактериальной наночеллюлозы. Выход сухой бактериальной наночеллюлозы составил 4.8 \%, степень полимеризации иеллюлозы 2010. Методом ИК-спектроскопии подтверждена химическая чистота иеллюлозы, термогравиметрическим анализом подтвержден типичныйхарактер разложения полимера, методом растровой электронной микроскопии показана характерная для бактериальной наноиеллюлозы сетчатая наноразмерная структура. Рентгенографическим методом установлено, что содержание триклинной модификации Іа в кристаллической составляющей бактериальной наноцеллюлозы $99 \%$, а степень кристалличности $88 \%$.

Ключевые слова: бактериальная наноиеллюлоза, химические аспекты, алломорф Iо, степень кристалличности.

\section{Введение}

Бактериальная наноцеллюлоза (БНЦ) представляет собой уникальный возобновляемый природный наноматериал, характеризующийся такими свойствами, как высокая механическая прочность, эластичность, пористость, влагоудерживающая способность, формуемость, биоразлагаемость и отличная биологическая совместимость. Эти свойства обуславливают широчайший спектр применения БНЦ: в медицине, пищевой, косметической, целлюлозно-бумажной, химической промышленностях, в создании современных акустических диафрагм и в других областях [1-8]. При этом химическая формула БНЦ, как и растительной целлюлозы, представляет собой линейный гомополимер из остатков $\mathrm{D}$-глюкозы, соединенных $\beta(1 \rightarrow 4)$-гликозидной связью. Но функциональные свойства БНЦ варьируют в широком диапазоне и зачастую зависят от применяемых питательных сред, продуцентов и условий культивирования [1-4].

Интенсивные исследования БНЦ в течение последних нескольких десятилетий в основном фокусировались на процессах получения, заменяющих синтетическую питательную среду на 
питательные среды из отходов пищевых производств и агропромышленного комплекса $[8,9]$. Результаты этих исследований должны быть использованы для создания технологии и организации промышленного производства БНЦ [2]. При переходе от синтетической на питательные среды из реальных общедоступных сырьевых источников химические аспекты синтеза БНЦ являются решающими. Для получения БНЦ важно наличие устойчивой сырьевой базы. По мнению многих исследователей, сырье должно быть массовым, доступным, дешевым, ежегодно воспроизводимым и обеспечивать высокий выход целевого продукта и его высокое качество без конкуренции с пищевым производством [2]. Среди многочисленных видов потенциального для БНЦ сырья отсутствуют плодовые оболочки овса (ПОО), кроме авторских работ [10]. Данное сырье характеризуется ежегодной воспроизводимостью и распространенностью в глобальном масштабе. Кроме того, ПОО имеют низкую себестоимость, так как затраты на выращивание включены в себестоимость зерна [11].

Способ получения БНЦ из ПОО включает в себя химические и биотехнологические аспекты. Характеристика БНЦ осуществляется физико-химическими методами аналогично растительной целлюлозе. Считаем, что главным критерием обоснованности выбранного нами технологического решения использования ПОО служат качественные показатели получаемой БНЦ.

Целью данной работы является исследование химических аспектов БНЦ, полученной переработкой ПОО.

\section{Материалы и методы}

Химический состав ПОО устанавливали по стандартным для растительного сырья методикам [12]. Массовую долю влаги определяли на анализаторе влажности «Ohaus» MB 23 (США).

ПОО подвергали последовательной обработке разбавленными растворами гидроксида натрия и азотной кислоты при атмосферном давлении и температуре $(94 \pm 2){ }^{\circ} \mathrm{C}$ с целью получения технической целлюлозы (ТЦ) [13] в условиях опытно-промышленного производства. Химический состав ТЦ определяли по стандартным методикам для продуктов химической обработки растительного сырья и целлюлозы [12].

В ферментере объемом 11 л при начальной концентрации 30 г/л техническую целлюлозу подвергали ферментативному гидролизу с использованием промышленно доступных ферментных препаратов «Целлолюкс-А» (производитель производственное объединение «Сиббиофарм», Россия) и BrewZyme BGX (производитель «Polfa Tarchomin Pharmaceutical Works S.A.», Польша, для компании «Diadic International Inc.», США) [14].

Концентрацию редуцирующих веществ (РВ) определяли в пересчете на глюкозу, использовали реактив на основе 3,5-динитросалициловой кислоты (Panreac, Испания) и спектрофотометр UNICO UV-2804 (США). Концентрацию пентоз в пересчете на ксилозу определяли на спектрофотометре с использованием железоорсинового реактива (производитель орсинола моногидрата 99 \%, CAS 6153-39-5, фирма Acrosorganics (США).

Ферментативный гидролизат отфильтровывали. Поскольку концентрация РВ выше требуемой и составила 30,8 г/л, то проводили стандартизацию по концентрации РВ 20 г/л следующим образом: экстракт черного байхового чая, приготовленный заранее, вносили в ферментативный гидролизат, тем самым разбавляя его до требуемой концентрации РВ. Для получения 
чайного экстракта навеску сухого черного байхового чая (5 г/л) экстрагировали при $100{ }^{\circ} \mathrm{C}$ в течение 1 мин, охлаждали до $30^{\circ} \mathrm{C}$ и фильтровали. В данном случае, чтобы приготовить 1 л питательной среды с концентрацией РВ 20 г/л, смешивали 649 мл ферментативного гидролизата и 351 мл экстракта черного байхового чая.

В полученную питательную среду вносили 7-дневную симбиотическую культуру Medusomyces gisevii Sa-12 в количестве 10 \% от используемого объема питательной среды: 100 мл культуры прибавляли к 900 мл питательной среды. Культивирование (синтез) с помощью Medusomyces gisevii Sa-12 проводили в условиях, обеспечивающих максимальный выход БНЦ [15]: культура стационарная, температура $27^{\circ} \mathrm{C}$, начальная концентрация РВ 20 г/л.

Полученные после завершения синтеза образцы БНЦ отделяли от питательной среды фильтрованием. Для удаления клеток микроорганизмов и красящих веществ БНЦ поэтапно промывали разбавленными растворами гидроксида натрия и соляной кислоты с последующей промывкой дистиллированной водой. Влажность БНЦ рассчитывали как разницу массы образца до и после высушивания в естественных условиях [16], и она составила $99.1 \%$. Эксперименты по получению БНЦ из ПОО проводили в трехкратной повторности.

Для определения выхода БНЦ, степени полимеризации целлюлозы и исследования ее физико-химическими методами (инфракрасная спектроскопия, термогравиметрический анализ, рентгенографический анализ) образцы высушивали на воздухе.

Для определения зависимости выхода БНЦ от продолжительности процесса синтеза в течение 24 сут через каждые четверо суток синтез прекращали съемом влажного образца БНЦ с поверхности питательной среды с последующей промывкой и сушкой.

Выход БНЦ рассчитывали по формуле

$$
\eta_{\text {Бц }}=\frac{m}{C_{\Gamma} \times V} \times 100 \%,
$$

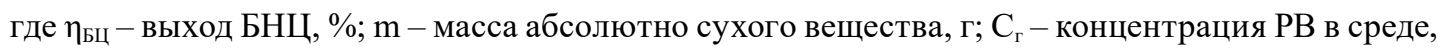
г/л; V - объем питательной среды, л.

Степень полимеризации БНЦ определяли методом, основанным на измерении времени истечения разбавленных растворов целлюлозы в кадоксене на капиллярном вискозиметре ВПЖ-3 с диаметром 0,92 мм (ГОСТ 25438-82).

Инфракрасная спектроскопия (ИК) образцов БНЦ проводилась на инфракрасном спектрофотометре «Инфралюм ФТ-801» (Россия) в таблетках КBr.

Термогравиметрический анализ (ТГА) образцов БНЦ проведен в следующих условиях: масса навески $1 \mathrm{мг,} \mathrm{скорость} \mathrm{нагрева} 10^{\circ} \mathrm{C} /$ мин, максимальная температура $600{ }^{\circ} \mathrm{C}$, инертная среда (азот) на термогравиметрическом анализаторе ДТЖ 60 (Россия).

Исследование морфологии БНЦ проводилось методом растровой электронной микроскопии (РЭМ) с помощью микроскопа JSM-840 (Япония). Для исследования методом РЭМ образцы БНЦ высушивали лиофильно.

Рентгенографический анализ образцов БНЦ проводили на дифрактометре ДРОН-6 (Россия) на монохроматизированном кристаллом пиролитического графита $\mathrm{Fe}-\mathrm{K}_{\alpha}$ излучении в интервале углов рассеяния от 3 до $145^{\circ}$. Спектральные характеристики рентгенограмм рассчитывали в программном комплексе PdWin. Подробно метод описан в статье [17]. 
Работа выполнена при использовании приборной базы Бийского регионального центра коллективного пользования СО РАН (ИПХЭТ СО РАН, г. Бийск).

\section{Обсуждение результатов}

Среди представленных в мировой литературе $[18,19]$ способов синтеза БНЦ способ получения из плодовых оболочек овса, кроме авторских разработок, отсутствует. Известно, что БНЦ напрямую из сырья получить невозможно. С химической точки зрения целлюлозосодержащее сырье представляет собой прочную матрицу, в которой гемицеллюлозы, лигнин и целлюлоза соединены физическими и химическими связями между собой. Поэтому для обеспечения открытого доступа ферментных препаратов к целлюлозе обязательной стадией является химическая предварительная обработка нативного целлюлозосодержащего сырья.

В данном случае предварительная химическая обработка ПОО позволила повысить содержание целлюлозы в полученном продукте - ТЦ почти в 2 раза, снизить содержание пентозанов в 2.8 раза, лигнина в 45 раз и золы в 23 раза (рис. 1). Сумма гидролизуемых компонентов после предварительной химической обработки в ТЦ увеличилась от $(75.5 \pm 0.3)$ до $(99.4 \pm 0,3) \%$, что обеспечивало эффективность ее ферментативного гидролиза.

Действительно, при проведении ферментативного гидролиза через 24 ч кривая роста концентрации РВ выходила на плато и составила 30 г/л (рис. 2). Такая высокая эффективность ферментативного гидролиза объясняется низкой начальной концентрацией ТЦ - 30 г/л, этого вполне достаточно для обеспечения необходимой концентрации РВ в питательной среде для БНЦ (от 20 до 25 г/л) [13]. Ферментативный гидролизат стандартизовали по содержанию РВ (20 г/л). Готовая питательная среда для биосинтеза БНЦ содержала 17.7 г/л глюкозы и 2.3 г/л ксилозы.

В процессе синтеза в первые сутки культивирования на поверхности питательной среды БНЦ не наблюдалось, на вторые сутки во всем объеме питательной среды наблюдались тонкие

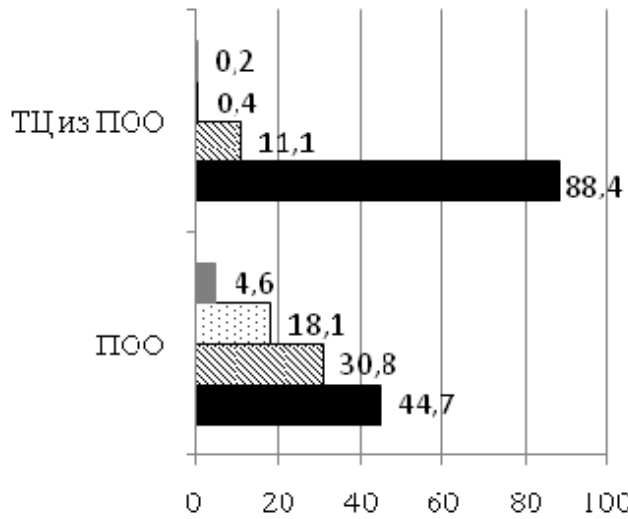

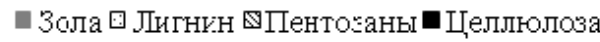

Рис. 1. Химический состав ПОО и технической целлюлозы из ПОО

Fig. 1. Chemical compositions of oat hulls and oat hull pulp

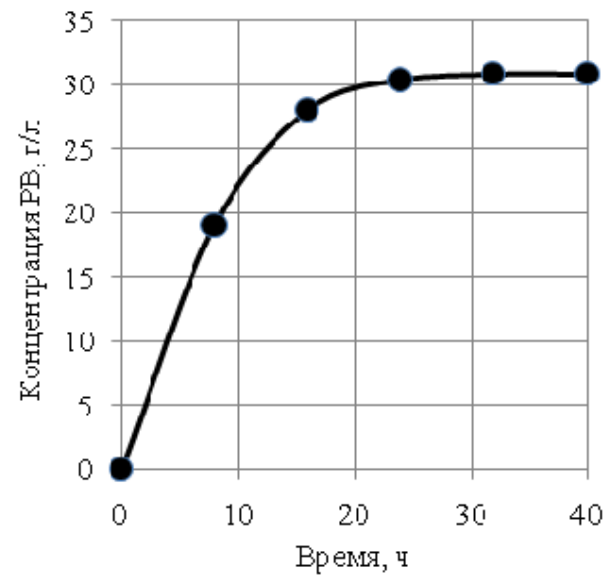

Рис. 2. Ферментативный гидролиз технической целлюлозы ПОО

Fig. 2. Enzymatic hydrolysis of oat hull pulp 


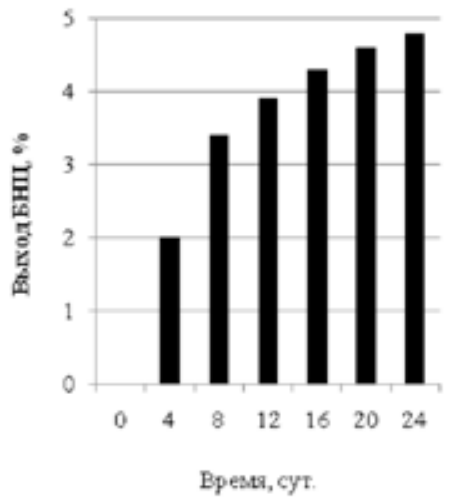

Рис. 3. Зависимость выхода БНЦ от продолжительности синтеза БНЦ

Fig. 3. BNC yield plotted against BNC synthesis time

нити БНЦ. В последующие сутки в верхнем слое питательной среды формировалась тонкая пленка БНЦ. Как следует из результатов исследования зависимости выхода БНЦ от продолжительности синтеза (рис. 3), основной синтез БНЦ происходил за 8 сут синтеза, выход в этот период увеличился до 3.4 \%. В период с 8 до 24 сут выход БНЦ увеличился до 4.8 \%. Из литературных данных известно, что выход БНЦ при ее синтезе на питательных средах из целлюлозосодержащего сырья с помощью индивидуальных штаммов может варьировать от 6.3 до 60.4 \% [20-22] и зависит, в первую очередь, от используемого продуцента. В данной работе невысокий выход БНЦ обусловлен использованием консорциума (сообщества) микроорганизмов, поддерживающих свою жизнедеятельность, утилизируя РВ для создания требуемой кислотности, выработки определенных веществ и параллельно с перечисленными процессами синтезируя БНЦ. Следует подчеркнуть, что при использовании аналогичного консорциума микроорганизмов на питательной среде из пищевой сахарозы выход БНЦ составил 0,67 \% [23]. В результате собственных исследований установлено, что данный консорциум микроорганизмов на питательной среде из ферментативного гидролизата ТЦ, полученной азотнокислым способом, составил 9 \% [10]. Степень полимеризации БНЦ на 7-е сут культивирования равнялась 2010.

В ИК-спектре образца БНЦ присутствовала интенсивная полоса при $3419 \mathrm{~cm}^{-1}$, которая указывала на валентные колебания ОН-групп. Менее интенсивные полосы в области $2896 \mathrm{~cm}^{-1}$ обусловлены валентными колебаниями групп $\mathrm{CH}_{2}, \mathrm{CH}$. В спектре БНЦ полосы при 1651 и $1539 \mathrm{~cm}^{-1}$ принадлежали деформационным колебаниям ОН-групп прочно связанной воды. Слабая полоса поглощения при $1428 \mathrm{~cm}^{-1}$ была обусловлена деформационными колебаниями групп $\mathrm{CH}_{2}$. Полосы при 1361, 1337, 1318 см$^{-1}$ характеризовали деформационные колебания ОН-групп. Полосы при 1281, 1249 и 12435 см$^{-1}$ указывали на деформационные колебания ОН-групп в спиртах. Полосы поглощения при 1204, 1164, $1073 \mathrm{~cm}^{-1}$ были обусловлены в основном валентными колебаниями С-О-С и С-О в спиртах [24] (рис. 4). Таким образом, методом ИК-спектроскопии подтверждено, что полученная БНЦ является химически чистым веществом, содержащим только целлюлозу.

На термогравиметрической кривой образца БНЦ выделили три участка (рис. 5). Первый участок связан с испарением легколетучих компонентов образца (воды): в диапазоне темпе- 


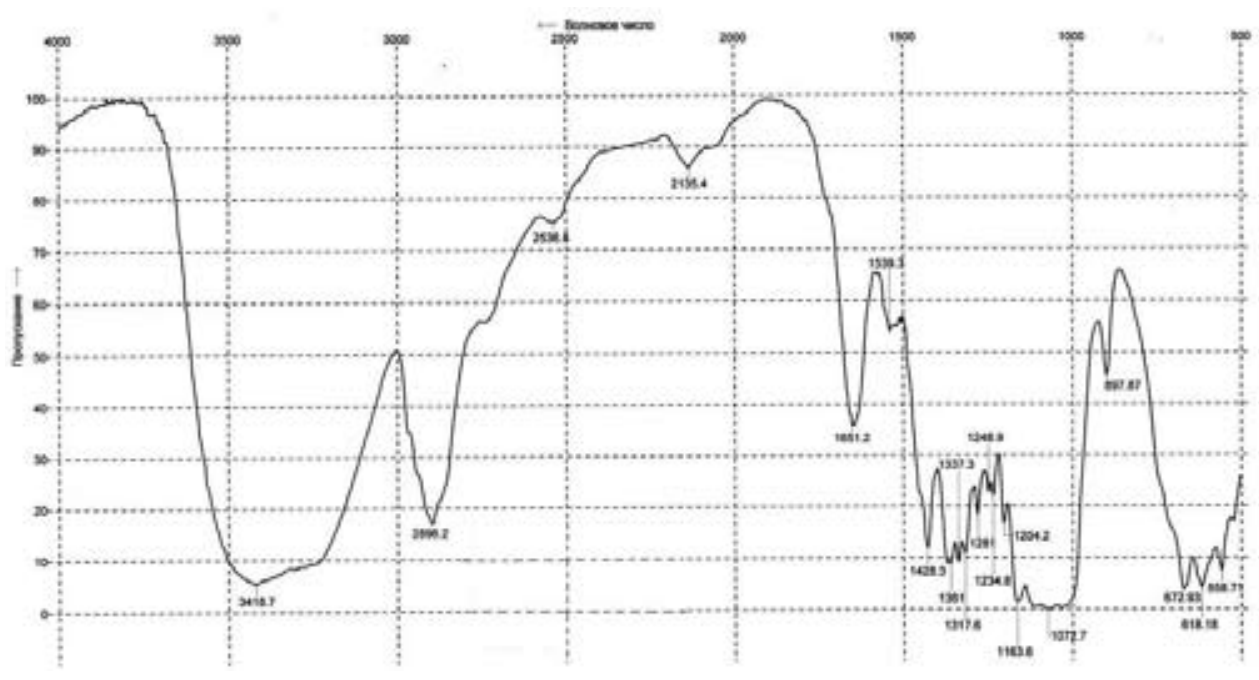

Рис. 4. ИК-спектр образца БНЦ

Fig. 4. IR spectrum of BNC

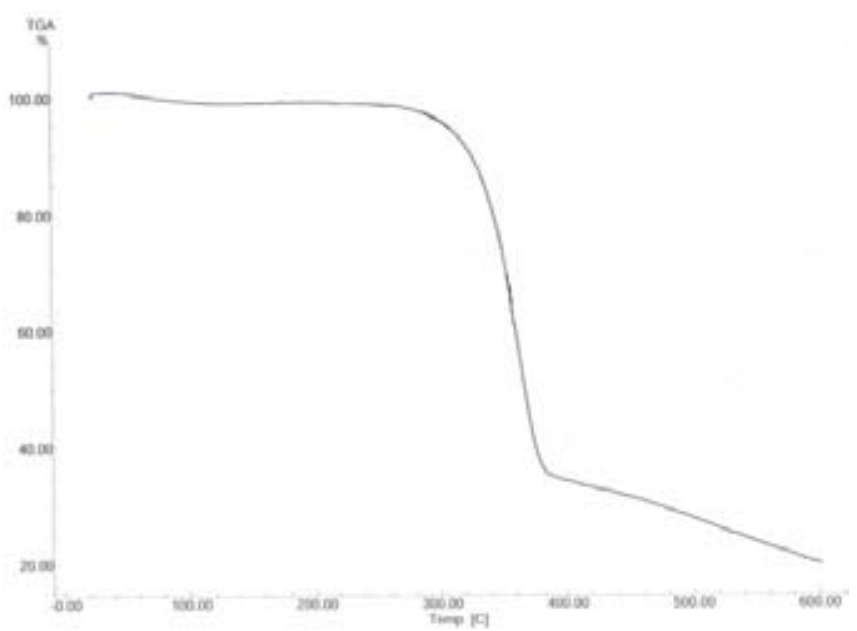

Рис. 5. Термогравиметрическая кривая образца БНЦ

Fig. 5. TGA curve of BNC

ратур от 38.1 до $154.5{ }^{\circ} \mathrm{C}$ изменение массы образца составило $3.1 \%$. Второй участок связан с разложением БНЦ в результате пиролиза: в диапазоне температур от 316.2 до $376.9{ }^{\circ} \mathrm{C}$ изменение массы образца составило $63.3 \%$. На третьем участке наблюдается доразложение материала: в диапазоне температур от 376.9 до $600{ }^{\circ} \mathrm{C}$ изменение массы образца составило 15.7 \%. Остаток - 20 \%. Полученные результаты хорошо коррелируют с описанными в литературе [25].

Свойства и применение БНЦ в основном зависят от ее сетчатой структуры [26], а одними из основных методов анализа сетчатой структуры служат методы микроскопии [2]. 


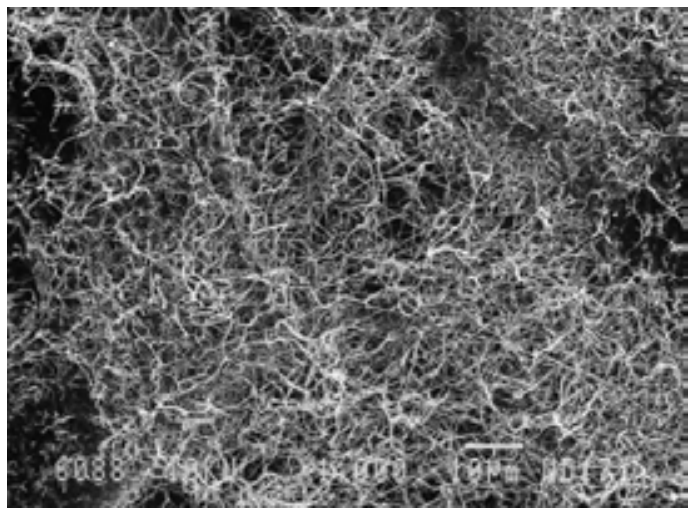

Рис. 6. Микрофотография образца БНЦ, ×1 000

Fig. 6. SEM image of BNC, $\times 1000$ zoom

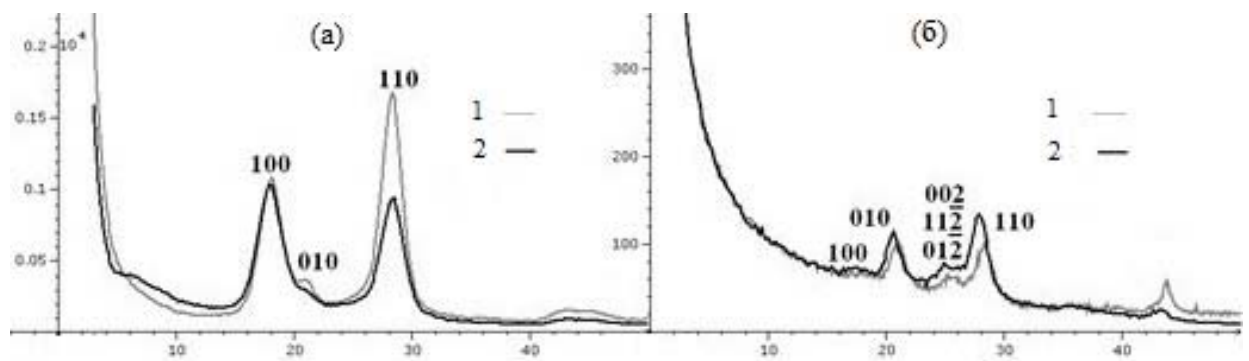

Рис. 7. Рентгенограммы образцов БНЦ, снятых на отражение (а) и на просвет (б); 1 - синтез БНЦ 7 сут, $2-10$ сут

Fig. 7. XRD images of BNC sin (a) reflection and (б) transmission: $1-\mathrm{BNC}$ synthesis for 7 days and $2-\mathrm{BNC}$ synthesis for 10 days

Исследования методом РЭМ показали, что образец БНЦ имеет сетчатую наноразмерную структуру (рис. 6), что является характерным и отличительным от растительной целлюлозы признаком БНЦ [27]. Толщина волокон БНЦ во много раз меньше толщины растительных фибрилл, а сетчатый характер структуры БНЦ определяет уникальные свойства данного материала.

Важнейшими характеристиками БНЦ, позволяющими отличить ее от любых других видов целлюлозы, являются наличие триклинной фазы I $\alpha$ в количестве от 56 до 90 \% [28, 29] и высокая степень кристалличности - от 28 до 88 \% [16, 22]. Эти показатели в исследуемом образце БНЦ определялись методом рентгеноструктурного анализа. На рис. 7 видно, что рентгенограммы образцов БНЦ, полученных на 7-е и 10-е сут синтеза, отснятые на отражение и просвет, резко различаются, что свидетельствует об анизотропии структуры БНЦ. Методом полнопрофильного анализа рентгенограмм поликристаллов было показано, что кристаллическая структура исследуемой целлюлозы на 99 \% соответствует триклинной фазе I $\alpha$.

Анализ литературы [1, 16, 22, 28-29], посвященной обсуждению результатов определения соотношения алломорфов целлюлозы I $\alpha: I \beta$ в образцах БНЦ, свидетельствует об изменении этого соотношения при модификации питательной среды и изменении условий синтеза, в част- 
ности об увеличении содержания алломорфа I $\beta$. Отличительной структурной характеристикой кристаллической составляющей образцов БНЦ из плодовых оболочек овса является преимущественное содержание алломорфа І $\alpha$. Обращает внимание высокая степень кристалличности БНЦ - $(88 \pm 5) \%$. Несмотря на невысокий выход БНЦ, очевидно, что уникальная структура экспериментальных образцов БНЦ из плодовых оболочек овса может определять особые области применения данного продукта.

\section{Заключение}

Предложен способ получения БНЦ из доступного непищевого целлюлозосодержащего сырья - плодовых оболочек овса. Данный способ включает предварительную химическую обработку плодовых оболочек овса с использованием разбавленных растворов гидроксида натрия и азотной кислоты с получением технической целлюлозы, ферментативный гидролиз технической целлюлозы, синтез БНЦ продуцентом Medusomyces gisevii Sa-12 на питательной среде из ферментативного гидролизата и химическую очистку БНЦ. Выход сухой БНЦ составил 4.8 \% в пересчете на массу РВ. Степень полимеризации целлюлозы, определенная вискозиметрическим методом в кадоксене, составила 2010.

ИК-спектроскопией установлено, что в результате синтезирована химически чистая целлюлоза. Результаты ТГА показали типичную картину разложения целлюлозы, начальная температура разложения составила $316.2{ }^{\circ} \mathrm{C}$, остаток - $20 \%$. Методом растровой электронной микроскопии установлена сетчатая наноразмерная структура. Среди известных способов синтеза БНЦ способ получения из плодовых оболочек овса отсутствует. В отличие от известных способов получения образцов БНЦ на питательных средах из гидролизатов отходов агропромышленного комплекса кристаллическая составляющая исследуемой БНЦ из плодовых оболочек овса характеризуется высоким содержанием (99 \%) триклинной модификации целлюлозы I $\alpha$, обладающей повышенной метастабильностью, а также установлена высокая степень кристалличности БНЦ $(88 \pm 5) \%$.

Исследование выполнено за счет гранта Российского научного фонда (проект № 17-1901054).

\section{Список литературы}

1. Heinze T., El Seoud O.A., Koschella A. Cellulose derivatives. Synthesis, structure, and properties. Switzerland: Springer, 2018. 552 p.

2. Gama M., Dourado F., Bielecki S. Bacterial nanocellulose from biotechnology to bio-economy. Amsterdam: Elsevier, 2016. 240 p.

3. Huang Y., Zhu C., Yang J., Nie Y., Chen C., Sun D. Recent advances in bacterial cellulose. Cellulose 2014. Vol. 21(1), P. 1-30.

4. Lin S.-P., Calvar I.L., Catchmark J.M., Liu J.-R., Demirci A., Cheng K.-C. Biosynthesis, production and applications of bacterial cellulose. Cellulose 2013. Vol. 20 (5), P. 2191-2219.

5. Gromovykh T.I., Lutcenko S.V., Feldman N.B., Kashirin V.V., Sadykova V.S., Dmitrenok A.S., Danilchuk T.N. Bacterial cellulose synthesized by Gluconacetobacter hansenii for medical applications. Applied Biochemistry and Microbiology 2017. Vol. 53(1), P. 60-67. 
6. Volova T.G., Shumilova A.A., Shidlovskiy I.P., Nikolaeva E.D., Sukovatiy A.G., Vasiliev A.D., Shishatskaya E.I. Antibacterial properties of films of cellulose composites with silver nanoparticles and antibiotics. PolymerTesting 2018. Vol. 65, P. 54-68.

7. Прудникова С.В., Шидловский И.П. Новый штамм уксуснокислых бактерий Komagataeibacter xylinus B-12068 - продуцент бактериальной целлюлозы для биомедицинского применения. Журнал Сибирского федерального университета. Серия: Биология 2017. T. 10(2), C. 246-254. [Prudnikova S.V., Shidlovsky I.P. The new strain of acetic acid bacteria Komagataeibacter xylinus B-12068 - producer of bacterial cellulose for biomedical applications. Journal of Siberian Federal University. Biology 2017. Vol. 10(2), P. 246-254. (In Russ.)]

8. Винник Ю.С., Маркелова Н.М., Шишацкая Е.И., Кузнецов М.Н., Прудникова С.В., Соловьева Н.С. Применение раневого покрытия на основе целлюлозы у больных с гнойными заболеваниями мягких тканей. Журнал Сибирского федерального университета. Серия: Биология 2016. Т. 9(1), С. 121-129. [Vinnik Yu.S., Markelova N.M., Shishackaya E.I., Kuznecov M.N., Prudnikova S.V., Solov'eva N.S. The Use of Wound Dressings Based on Cellulose in Patients with Purulent Diseases of Soft Tissues. Journal of Siberian Federal University. Biology 2017. Vol. 9(1), P. 121-129. (In Russ.)]

9. Богатырева А.О., Сапунова Н.Б., Щанкин М.В., Лияськина Е.В., Ревин В.В. Получение бактериальных экзополисахаридов на средах с отходами биотехнологических производств. Вестник Технологического университета 2016. Т. 19(24), С. 142-145. [Bogatyreva A.O., Sapunova N.B., Shchankin M.V., Liyas'kina E.V., Revin V.V. Exopolysaccharides obtained on media with biotechnologicall production waste. Bulletin of the Technological University 2016. Vol. 19(24), P. 142-145. (In Russ.)]

10. Гладышева Е.К., Скиба Е.А. Биосинтез бактериальной целлюлозы на ферментативном гидролизате технической целлюлозы из плодовых оболочек овса, Известия вузов. Прикладная химия и биотехнология. 2017, Т. 7(1), C. 141-147. [Gladysheva E.K., Skiba E.A. Biosynthesis of bacterial cellulose on enzymatic hydrolyzate of oat hull pulp. News of universities. Applied Chemistry and Biotechnology 2017. Vol. 7(1), P. 141-147. (in Russ.)]

11. Sakovich G.V., Skiba E.A., Budaeva V.V., Gladysheva E.K., Aleshina L.A. Technological Fundamentals of Bacterial Nanocellulose Production from Zero Prime-Cost Feedstock. Doklady Biochemistry and Biophysics 2017. Vol. 477, P. 357-359.

12. Оболенская А.В., Ельницкая 3.П., Леонович А.А. Лабораторные работы по химии древесины и целлюлозы. Москва: Экология, 1991, с. 71-168. [Obolenskaya A.V., El'nickaya Z.P., Leonovich A.A. Laboratory work on the chemistry of wood and cellulose. Moscow: Ecology, 1991, P. 71-168. (In Russ.)]

13. Скиба Е.А., Будаева В.В., Макарова Е.И., Павлов И.Н., Золотухин В.Н., Сакович Г.В. Ферментативный гидролиз целлюлоз плодовых оболочек овса. Вестник Казанского технологического университета 2013. T. 16(20), C. 195-198. [Skiba E.A., Budaeva V.V., Makarova E.I., Pavlov I.N., Zolotuhin V.N., Sakovich G.V. Enzymatic hydrolysis of oat hull pulps. Bulletin of the Kazan Technological University 2013. Vol. 16 (20), P. 195-198. (In Russ)]

14. Кащеева Е.И., Будаева В.В. Определение реакционной способности к ферментативному гидролизу целлюлозосодержащих субстратов. Заводская лаборатория. Диагностика ма- 
териалов 2018. T. 84(10), С. 5-11. [Kashcheeva E.I., Budaeva V.V. Determination of the reactivity of cellulosic substrates towards enzymatic hydrolysis. Zavodksaya Laboratoriya. Diagnostika Materialov 2018. Vol. 84(10), P. 5-11. (In Russ)]

15. Gladysheva E.K., Skiba E.A., Zolotukhin V.N., Sakovich G.V. Study of the Conditions for the Biosynthesis of Bacterial Cellulose by the Producer Medusomyces gisevii Sa-12. Applied Biochemistry and Microbiology 2018. Vol. 54(2), P. 165-174.

16. Tsouko E., Kourmentza C., Ladakis D., Kopsahelis N., Mandala I., Papanikolaou S., Paloukis F., Alves V., Koutinas A. Bacterial cellulose production from industrial waste and by-product streams. International Journal of Molecular Sciences 2015. Vol. 16(7), P. 14832-14849.

17. Torlopov M.A., Mikhaylov V.I., Udoratina E.V., Aleshina L.A., Prusskii A.I., Tsvetkov N.V., Krivoshapkin P.V. Cellulose nanocrystals with different length-to-diameter ratios extracted from various plants using novel system acetic acid/phosphotungstic acid/octanol-1. Cellulose 2018. Vol. 25(2), P. 1031-1046.

18. Islam U.M., Ullah M.W., Khana S., Shahc N., Parka J.K. Strategies for cost-effective and enhanced production of bacterial cellulose. International Journal of Biological Macromolecules 2017. Vol. 102, P. 1166-1173.

19. Filho W.L., Pociovalisteanu D.M., Al-Amin A.Q. Sustainable economic development. Green economy and green growth. Switzerland: Springer international publishing 2017, $331 \mathrm{p}$.

20. Yang X.-Y., Huang C., Guo H.-J., Xiong L., Li Y.-Y., Zhang H.-R., Chen X.-D. Bioconversion of elephant grass (Pennisetum purpureum) acid hydrolysate to bacterial cellulose by Gluconacetobacter xylinus. Journal of Applied Microbiology 2013. Vol. 115 (4), P. 995-1002.

21. Hong F., Qiu K. An alternative carbon source from konjac powder for enhancing production of bacterial cellulose in static cultures by a model strain Acetobacter aceti subsp.xylinus ATCC 23770. Carbohydrate Polymers 2008. Vol. 72 (3), P. 545-549.

22. Goelzer F.D.E., Faria-Tischer P.C.S., Vitorino J.C., Sierakowski M.R., Tischer C.A. Production and characterization of nanospheres of bacterial cellulose from Acetobacter xylinum from processed rice bark. Materials Science and Engineering 2009. Vol. 29(2), P. 546-551.

23. Goh W.N., Rosma A., Kaur B., Fazilah A., Karim A.A., Rajeev B. Fermentation of black tea broth (Kombucha): I. Effects of sucrose concentration and fermentation time on the yield of microbial cellulose. International Food Research Journal 2012. Vol. 19 (1), P. 109-117.

24. Yin X., Yu C., Zhang X., Yang J., Lin Q., Wang J., Zhu Q. Comparison of succinylation methods for bacterial cellulose and adsorption capacities of bacterial cellulose derivatives for $\mathrm{Cu} 2+$ ion. Polymer Bulletin 2011. Vol. 67(3), P. 401-412.

25. Cheng K., Catchmark J., Demirci A. Enhanced production of bacterial cellulose by using a biofilm reactor and its material property analysis. Journal of Biological Engineering 2009. Vol. 3(12), P. 1-10.

26. Baruda H.G. de Oliveira, Silvac R.R., Barud H. da Silva, Tercjakd A., Gutierrezd J., Lustrib W.R., Juniora O.B. de Oliveira, Ribeiroca S.J.L. A multipurpose natural and renewable polymer in medicalapplications: Bacterial cellulose. Carbohydrate Polymers 2016. Vol. 153, P. 406-420.

27. Goh W.N., Rosma A., Kaur B., Fazilah A., Karim A.A., Rajeev B. Microstructure and physical properties of microbial cellulose produced during fermentation of black tea broth (Kombucha) II. International Food Research Journal 2012. Vol. 19(1), P. 153-158. 
28. Vazquez A., Foresti M.L., Cerrutti P., Galvagno M. Bacterial cellulose from simple and low cost production media by Gluconacetobacter xylinus. Journal of Polymers and the Environment 2013. Vol. 21(2), P. 545-554.

29. Zhou L.L., Sun D.P., Hu L.Y., Li Y.W., Yang J.Z. Effect of addition of sodium alginate on bacterial cellulose production by Acetobacter xylinum. Journal of industrial Microbiology and Biotechnology 2007. Vol. 34, P. 483-489. 